Article

\title{
Trade-Offs between Sugarcane Straw Removal and Soil Organic Matter in Brazil
}

\author{
Maristela C. Morais ${ }^{1, *(\mathbb{D}}$, Marcos Siqueira-Neto ${ }^{1,2}{ }^{\mathbb{D}}$, Henrique P. Guerra ${ }^{1}$, Lucas S. Satiro ${ }^{3}$, \\ Amin Soltangheisi ${ }^{1}\left(\mathbb{D}\right.$, Carlos E. P. Cerri $\left.^{3}{ }^{(}\right)$, Brigitte J. Feigl $^{1}$ and Maurício R. Cherubin $^{3, *}$ (1) \\ 1 Center for Nuclear Energy in Agriculture, University of São Paulo, Piracicaba SP 13416-900, Brazil; \\ msiqueir@gmail.com (M.S.-N.); henrique.guerra@alumni.usp.br (H.P.G.); soltangheise@gmail.com (A.S.); \\ beduardo@cena.usp.br (B.J.F.) \\ 2 Center of Agrarian and Environmental Science, Federal University of Maranhão, \\ Chapadinha MA 65500-000, Brazil \\ 3 “Luiz de Queiroz" College of Agriculture, University of São Paulo, Piracicaba SP 13416-900, Brazil; \\ satiro@alumni.usp.br (L.S.S.); cepcerri@usp.br (C.E.P.C.) \\ * Correspondence: maristelacm@usp.br (M.C.M.); cherubin@usp.br (M.R.C.); \\ Tel.: +55-19-99629-1966 (M.C.M.); +55-19-3429-4728 (M.R.C.)
}

Received: 22 September 2020; Accepted: 9 November 2020; Published: 11 November 2020

\begin{abstract}
Environmental benefits from bioenergy production derived from sugarcane crop residues (straw) can be lost by soil organic matter depletion resulting from excessive straw removal rates from fields. Soil organic carbon stock is the core for sustaining soil health, supporting nutrient cycling, and sequestering carbon dioxide. To find out that how much sugarcane straw can be removed from the field to produce bioenergy without changes in soil C concentrations, we investigated effects of straw removal rates (total, moderate, and no removal of sugarcane straw) on soil carbon and nitrogen fractions in an Oxisol and an Ultisol in southeastern Brazil for two years. Soil C and N fractions were affected by increased rates of straw removal at the second year. In the Oxisol, total straw removal decreased labile and microbial-C by $\sim 30 \%$ and soil $C$ stock by $20 \%$ compared to no straw removal. No removal decreased microbial-N and total $\mathrm{N}$ stock by $\sim 15 \%$ and $\sim 20 \%$, respectively. In the Ultisol, no straw removal resulted in increases in $C$ stock by $>10 \%$ and labile and microbial-C by $\sim 20 \%$ related to total straw removal. Total straw removal showed more microbial-N $(\sim 10 \%)$ and total-N stock $(\sim 25 \%)$ compared to no straw removal. The moderate straw removal intensity (i.e., 8 to $10 \mathrm{Mg} \mathrm{ha}^{-1}$ of straw) may control the straw-C release to soil by straw decomposition. This study suggests that excessive straw removal rates should be avoided, preventing SOM depletion and consequently, soil health degradation. Moderate straw removal seems to be a promising strategy, but long-term soil C monitoring is fundamental to design more sustainable straw management and bioenergy production systems.
\end{abstract}

Keywords: crop residue management; soil organic matter quality index; bioenergy

\section{Introduction}

A global effort has been done to diversify energy sources and reduce the consumption of fossil fuels towards a planet safe from environmental threats [1]. Renewable energy sources account for nearly $24 \%$ of the total world energy demand while fossil fuels supplied about $70 \%$ of the demand for fuels in 2018 [2]. Biomass energy is one of the new renewable energy technologies that are now under development with potential to provide energy free or nearly free of emitting greenhouse gases [3]. As Brazil is the world's largest sugarcane producer, accounting for $40 \%$ of global production with 35.3 million tons of sugar and 29.3 billion L of ethanol [4], the sugarcane straw in commercial farms 
represents a viable feedstock for biomass energy production [5]. The area devoted for sugarcane harvest in 2020 will be around 8.4 million hectares mainly concentrated in the south-central Brazil, representing more than $92 \%$ of sugarcane production.

For a long time, Brazilian sugarcane fields have been burned for manual harvesting and transportation, however to reduce the negative environmental impacts such as air pollution and health issues [6], there was a shift from burned to a non-burned harvest system with implementation of legislation in some states [7]. With gradual change on harvest systems in the last decade, the south-central region of Brazil has more than $90 \%$ of sugarcane fields being harvested mechanically in a green cane system management [8]. In this system, most of the sugarcane straw is maintained on the soil surface, equivalent to, on average, $14 \mathrm{Mg} \mathrm{ha}^{-1} \mathrm{yr}^{-1}$ of straw (dry weight) in Brazilian sugarcane fields [9], which results in annual straw-carbon (C) inputs into the soil [10]. However, the amount of straw produced, and the soil $\mathrm{C}$ retention depend on climatic conditions, sugarcane type, and management practices.

In sugarcane fields, the preservation of straw on the soil surface may have some disadvantages such as disease proliferation and increased risk of fires [11]. On the other hand, straw mulching was indicated as beneficial to the improvement of soil nutrient cycling and water retention and the reduction of soil susceptibility to compaction and erosion processes [12-16]. In addition, previous studies indicated that straw maintained on the soil surface is an additional source of $C$, which can be transformed into soil organic matter [17]. Because the existing soil $C$ in terrestrial ecosystems is greater than the atmospheric and the biotic $C$ pools, in which soil organic carbon (SOC) accounts for more than half of the global soil $C$ pool [18], land use and soil management determine if terrestrial $\mathrm{C}$ pool is a source or sink of atmospheric $\mathrm{CO}_{2}$ [19], which influences climate change adaptation and mitigation [20].

Soil organic matter (SOM) has a multifunctional role in sustaining soil health by influencing not only biological processes, but also chemical and physical functions [21,22]. As preservation of soil C pools is critical to sustain soil ecosystem services and mitigate the global climate change with soil C sequestration $[5,23]$, there is a substantial interest in identifying management strategies that improves stable SOM accumulation [8]. Therefore, the adoption of bioenergy crop managements contributing to SOC increase or maintenance has an important role to sustain soil health in the long-term $[24,25]$.

While the effects of sugarcane straw removal on labile fractions of SOM are not yet widely explored, the preservation of soil labile $\mathrm{C}$ pools has advantages for a more sustainable crop management, such as immobilization of soil nutrients, aggregate formation, microorganisms and enzyme activities enhancement, and soil $C$ pools protection [26-28]. Since labile $C$ is more sensitive to soil management systems, it provides a better measurement of $C$ dynamics in the short term related to $C$ stock alone and can be used as predictor of SOM changes [29-32]. Although recent field studies have investigated the impact of sugarcane straw removal on soil C stocks, there is still relatively little information about the effects of straw removal rates on sensible and labile fractions of SOM, particularly in tropical areas under sugarcane cultivation.

Thus, field experiments are necessary to investigate the effect of different straw removal rates on soil organic matter fractions in sugarcane fields and quantify the amount of straw that can be removed without negative impacts on soil quality and crop production. Such information is essential for helping farmers to adopt best soil management practices, which sustain or even increase SOM contents. Therefore, experiments in two south-central Brazilian sugarcane fields were designed to test the hypothesis that bioenergy can be generated from sugarcane crop residues by a certain rate of straw removal from field without causing negative impacts on soil organic matter and environment. The objectives of this study were to evaluate the influence of different amounts of straw removal on the labile fractions of soil organic matter as well as on the soil carbon and nitrogen stocks in sugarcane farms in southeast Brazil. 


\section{Materials and Methods}

\subsection{Study Area and Experimental Design}

The experimental sites represented typical conditions of sugarcane growing in São Paulo (SP) state, southeast Brazil, which is situated inside of the south-central region of sugarcane production. Two field experiments were carried out within commercial farms in the Oxisol site (Capivari-SP; Lat. $22^{\circ} 59^{\prime} 42^{\prime \prime}$ S; Long. $47^{\circ} 30^{\prime} 34^{\prime \prime} \mathrm{W}$ ) and in the Ultisol site (Valparaíso-SP; Lat. $21^{\circ} 14^{\prime} 48^{\prime \prime}$ S; Long. $50^{\circ} 52^{\prime} 04^{\prime \prime} \mathrm{W}$ ). The climate under the Oxisol and Ultisol soils are subtropical (Cwa type-Köppen-Geiger classification) and tropical (Aw type), respectively. During the experiment, in the Oxisol site mean annual temperature was $21^{\circ} \mathrm{C}$ and mean annual precipitation was $1365 \mathrm{~mm}$, and in the Ultisol site mean annual temperature was $24^{\circ} \mathrm{C}$ and mean annual precipitation was $1549 \mathrm{~mm}$ (Figure 1). Soils were classified as sandy clay loam soil (Oxisol) and sandy loam soil (Ultisol) [33].

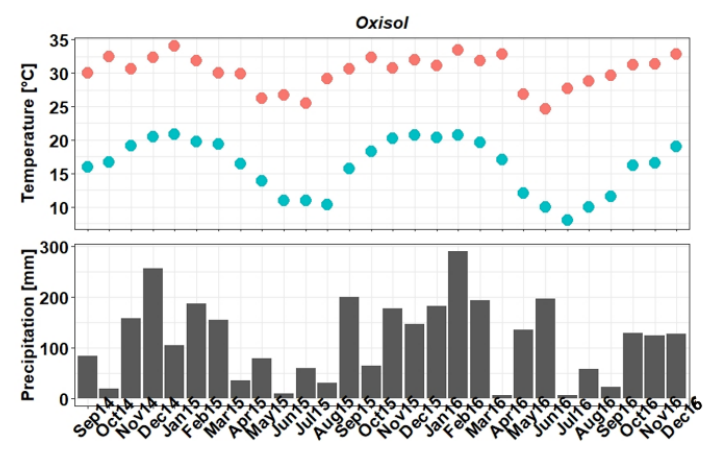

(a)
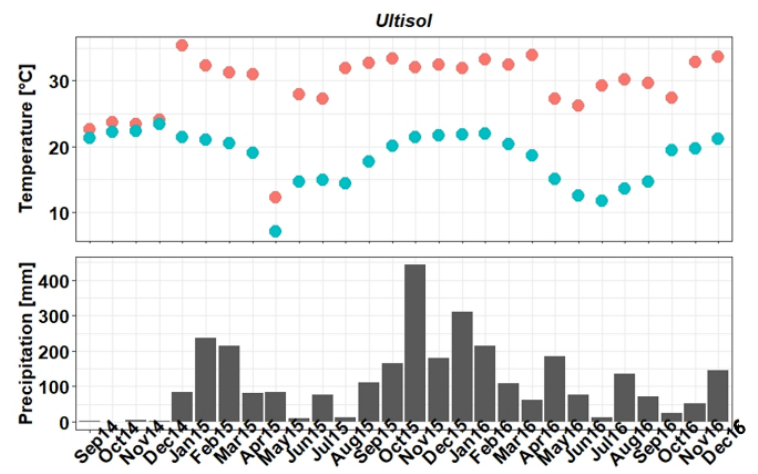

(b)

Figure 1. Climate characteristics of studied regions. Monthly maximum (red dots) and minimum (blue dots) temperature $\left({ }^{\circ} \mathrm{C}\right.$ ) and precipitation $(\mathrm{mm})$ in the region studied during 2014 (experiment establishment) and 2016 (last growing season) years: (a) Oxisol site (Capivari-São Paulo, Brazil); (b) Ultisol site (Valparaíso-São Paulo, Brazil). Sources: CANACAP (http://www.canacap.com.br) and Valparaiso Experimental Station/UFSCar (http://pmgca.dbv.cca.ufscar.br).

The field experiments were initiated at each location in February 2013 with sugarcane planting of cultivars CTC-15 and RB86-7515 in the Oxisol and in the Ultisol, respectively. Three treatments were arranged in a randomized block design with four replications within each area after the harvesting of plant cane in October 2014. The treatments comprised of three straw removal rates (total [S- -], moderate [S-] and no removal [S]). In both experiments, the straw was composed of about 30\% of tops and green leaves and about $70 \%$ of dry leaves. The size of each individual plot was $50 \times 20 \mathrm{~m}$, comprising 12 experimental plots with rows of 0.9 and $1.5 \mathrm{~m}$ apart from each site. The assessment of straw removal rates and the determination of the biomass were achieved by an experiment with harvester extractors manipulation and calibration [34]. At that time, soil samples were collected for baseline characterization of the sites (Table 1).

Table 1. Soil texture and chemical properties in the two experimental sites.

\begin{tabular}{|c|c|c|c|c|c|c|c|c|c|c|c|c|}
\hline Local & Clay & Silt & Sand & $\mathrm{C}$ & Bulk Density & $\mathrm{pH}$ & $\mathrm{Ca}$ & $\mathrm{Mg}$ & $\mathbf{K}$ & BS & CEC & $\begin{array}{c}\mathrm{P} \\
\mathrm{mg} \mathrm{kg}^{-1}\end{array}$ \\
\hline Oxisol & 330 & 60 & 610 & 11.3 & 1.32 & 5.2 & 26.1 & 7.7 & 9.3 & 68.8 & 62.6 & 29.3 \\
\hline
\end{tabular}

${ }^{1}$ The determination of soil texture was based on Buyoucos method. ${ }^{2}$ Dry combustion method by an elemental analyzes ${ }^{3} \mathrm{pH}$ measured in water. ${ }^{4} \mathrm{Ca}, \mathrm{Mg}$, and $\mathrm{K}$ : extraction with ion exchange resin and determination in a spectrophotometer of atomic absorption. ${ }^{5}$ Colorimetric method extracted with ion exchange resin. 
The same procedures were performed in the re-establishment of trials after harvest of the first ratoon (December 2015) (Figure 2). The total dry matter of each treatment is presented in Table 2.

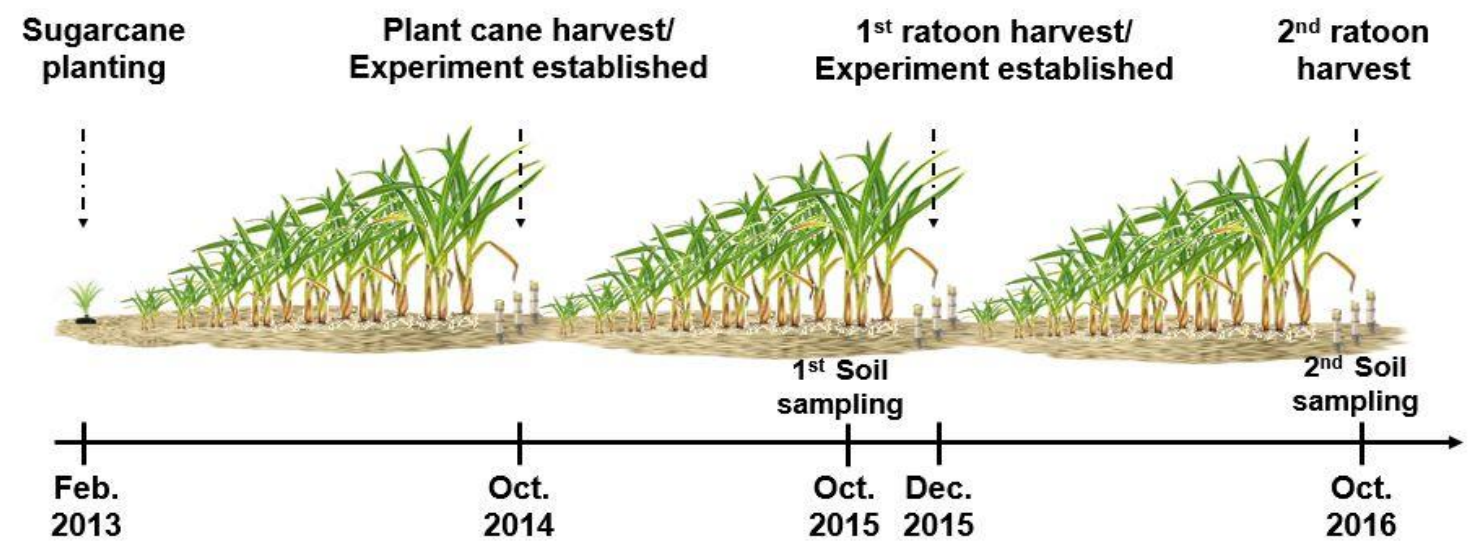

Figure 2. Experimental activities timeline during three growing seasons of sugarcane cycle.

Table 2. Amount of sugarcane straw ( $\mathrm{Mg} \mathrm{ha}^{-1}$ of dry mass) maintained on soil surface for each treatment in after experiment establishment in each area.

\begin{tabular}{ccc}
\hline Treatments & Oxisol & Ultisol \\
\hline Total removal [S-] & 0 & 0 \\
Moderate removal [S-] & 8.7 & 10.2 \\
No removal [S] & 18.9 & 16.4 \\
\hline
\end{tabular}

\subsection{Soil Sampling and Analysis}

In October 2015, soil samples were collected from 0-10 $\mathrm{cm}$ layer in both sites for assessing the potential effects of the treatments, even after a short-term period (i.e., one year under straw cover). After harvesting the second ratoon of sugarcane, soil was sampled for the second time in both sites to determine total organic carbon $\left(\mathrm{C}_{t o t}\right)$, total nitrogen $\left(\mathrm{N}_{t o t}\right)$, labile fraction of carbon $\left(\mathrm{C}_{l a b}\right)$, and carbon and nitrogen microbial biomass $\left(\mathrm{C}_{m i c}, \mathrm{~N}_{m i c}\right)$. To represent the heterogeneity of the system, composite soil samples were collected randomly from the rows within each plot. To determine the bulk density, undisturbed soil samples were collected using $5-\mathrm{cm}$ (diameter) by 5 -cm (height) stainless steel cylinders. The total mass and water content were quantified, and bulk density was calculated (soil dry mass/ring volume).

$\mathrm{C}_{\text {tot }}$ and $\mathrm{N}_{\text {tot }}$ were measured in air-dried soil samples sieved through 100 mesh with dry combustion method by an elemental analyzer (LECOC TruSpec ${ }^{\circledR}$ CN, St Joseph, MI, USA). The fumigation-extraction [35] was used to estimate soil microbial biomass extractable with $0.5 \mathrm{M}$ $\mathrm{K}_{2} \mathrm{SO}_{4}$ from fumigated and non-fumigated soils. $\mathrm{C}_{\text {mic }}$ and $\mathrm{N}_{\text {mic }}$ concentrations were determined using Shimadzu@ TOC-VCPN ${ }^{\circledR}$ (Tokyo, Japan) coupled with a module Shimadzu@ TNM-1 ${ }^{\circledR}$ (Tokyo, Japan). Extraction factor of $0.33\left(\mathrm{~K}_{C}\right)$ and $0.54\left(\mathrm{~K}_{N}\right)$ were considered to estimate $\mathrm{C}_{\text {mic }}$ [36] and $\mathrm{N}_{\text {mic }}$ [37] concentration, respectively. $\mathrm{C}_{\text {lab }}$ was considered as the $\mathrm{K}_{2} \mathrm{SO}_{4}$-extractable carbon from fumigated soil [38]. Stocks were calculated using $C$ and $N$ concentrations, soil bulk density and soil depth $(10 \mathrm{~cm})$. Stock correction was performed with the same mass of soil using bulk density from no removal treatment of each site as reference, according to the literature [39].

Soil carbon and nitrogen indexes were calculated based on the amounts of total, microbial, and labile $\mathrm{C}$, as well as total and microbial $\mathrm{N}$. Total $\mathrm{C}$ and $\mathrm{N}$ were used to calculate $\mathrm{C}: \mathrm{N}$ ratio. Microbial $\mathrm{C}$ and $\mathrm{N}$ were used to calculate $\mathrm{C}_{\text {mic }}: \mathrm{N}_{\text {mic }}$ ratio. The $\mathrm{C}_{\text {lab }}: \mathrm{C}_{\text {tot }}, \mathrm{C}_{\text {mic }}: \mathrm{C}_{\text {lab }}, \mathrm{C}_{\text {mic }}: \mathrm{C}_{\text {tot }}$, and $\mathrm{N}_{\text {mic }}: \mathrm{N}_{\text {tot }}$ indexes were also calculated.

In October 2016, physical fractionation of SOM was carried out to investigate $C$ accumulation in each soil compartment due to the levels of straw removal in samples collected from $0-5$ and 
5-10-cm layers. This technique is useful to characterize and quantify the compartments of SOM with different responses to soil management practices [40]. The physical fractionation of SOM followed the methodology described in the literature [41], grouping into large size particles $(2.000-53-\mu \mathrm{m})$, small size particles $(<53-\mu \mathrm{m})$, and free organic material fractions (FOM). Soil samples were air dried and passed through a 2-mm sieve, and $20 \mathrm{~g}$ of sample was extracted with $70 \mathrm{~mL}$ of deionized water. The soil solution was sonicated using an ultrasonicator Vibra-Cell ${ }^{\mathrm{TM}}$ Ultrasonic Liquid Processors Sonics ${ }^{\circledR}$ model VCX 500 (Newton, CO, USA), equipped with a converter (Model CV 334) and a high intensity titanium alloy sonotrode with $13 \mathrm{~mm}$ of diameter, immersed $20 \mathrm{~mm}$. The generator power output control was set at $70 \%$ (approximately $50 \mathrm{~J} \mathrm{~g}^{-1}$ of soil) with a frequency of $20 \mathrm{kHz}$ for $15 \mathrm{~min}$. After dispersion, the soil extract was passed through a $0.53-\mathrm{mm}$ sieve to separate the sand large size particle fraction. The remaining was dried to determine the small size particles. After that, each fraction was dried at $40^{\circ} \mathrm{C}$, weighed, and total-C content was determined with dry combustion.

\subsection{Statistical Analysis}

The statistical analysis of data was performed using the software Statistical Analysis System (SAS Inc., Cary, NC, USA), version 9.3. Analysis of variance (ANOVA) was used to assess differences among treatments (total, moderate and no straw removal) within each paired area (Oxisol and Ultisol). The normality of data was checked by Shapiro-Wilk's test $(p>0.05)$. Data transformation was not required to meet ANOVA assumptions. If the ANOVA results were significant $(p<0.10)$, average values of dependent variables were compared using Tukey's test $(p<0.10)$. Differences between the two areas were not evaluated due to distinct soil attributes and sugarcane cultivars.

\section{Results}

\subsection{Soil Carbon and Nitrogen Concentration and Stocks}

In the Oxisol and Ultisol, soil $\mathrm{C}_{t o t}, \mathrm{~N}_{t o t}$ and $\mathrm{C}_{\text {mic }}$ stocks were not affected by straw removal in 2015 ( $p>0.1$, Figure 3a-d), and in the Oxisol site, the $C_{l a b}$ stock was the highest in the sugarcane plots with moderate straw removal [S-] $\left(p<0.10\right.$; Figure 3e). The $\mathrm{N}_{\text {mic }}$ stock was influenced by total sugarcane straw removal from the field [S- -] $(p<0.10$; Figure 3j) in the Ultisol site. Soil C and N concentrations and stocks in the first year of experiment (2015) did not respond to straw removal rates in both locations. In contrast, the effects of straw removal showed significant depletion of soil microbial $\mathrm{N}$ stock upon complete removal of the sugarcane straw under Ultisol $(p<0.10$; Figure 3j), suggesting that straw removal enhances the soil $\mathrm{N}$ mineralization due to the limited source of $C$ for microbiota.

In both experimental sites in 2016, soil $\mathrm{C}_{\text {lab }}$ and $\mathrm{C}_{\text {mic }}$ stocks were the highest in the plots that sugarcane straw was maintained in the surface soil $(p<0.1$, Figure $3 c-f)$ and the concentration of those attributes in soil followed the same trend ( $p<0.1$ Supplementary material; Table S1), indicating an increase in labile and microbial fractions of soil $\mathrm{C}$ with decreasing in straw removal rates in both areas. In the Ultisol, surface soil $\mathrm{C}_{\text {tot }}$ stock was higher in the soil without straw removal [S] compared to the soil with moderate [S-] and total straw removal [S- - ] $\left(p<0.1\right.$, Figure 3b). In the Oxisol, the soil $\mathrm{C}_{\text {tot }}$ was also higher in plots with straw on the soil surface, although there was no significant difference between the two rates: moderate [S-] and no removal [S] ( $p<0.1$, Figure 3a). In contrast to the effects of straw removal in 2015 observed in this study, the overall effects of the straw removal for two years showed significant depletion of soil C stocks, comparing complete straw removal with no removal [S].

Soil $\mathrm{C}$ and $\mathrm{N}$ concentrations were affected by sugarcane straw removal in both sites. In the Oxisol site, soil $C_{\text {tot }}$ concentration was the highest in the soils with moderate and no straw removal, while in the Ultisol, the difference was only observed between [S- -] and [S] ( $p<0.10$; Supplementary material, Table S1). The soil $\mathrm{N}_{t o t}$ and $\mathrm{N}_{\text {mic }}$ concentrations in the [S- -] and [S-] treatments were higher than the treatments without straw removal $(p<0.10$; Supplementary material). In the Ultisol site, the soil $\mathrm{N}_{\text {tot }}$ concentration was influenced by no removal of sugarcane straw [S] compared to total removal [S- - $(p<0.10$; Supplementary material, Table S1), and since the same trend was observed 
for soil N stock, this probably occurred due to the increase in C concentration (due to both the straw deposition [in S and S-], and the root system renovation [in all treatments]), which actives soil microbial biomass, and consequently, favoring the net $\mathrm{N}$ mineralization. Mineralized N derived from SOM can be absorbed by the culture, or in a worse situation, may be removed from the system by leaching or as gaseous forms. In the first year of experiment, labile $\mathrm{C}$ and microbial $\mathrm{N}$ fractions were more sensitive to straw removal compared to total $C$ (Figure 3e,j). After two years, not only these two $C$ fractions but also total $C$ stocks were influenced by straw removal rates, indicating that the complete removal of straw could reduce soil $C$ stock in long term.

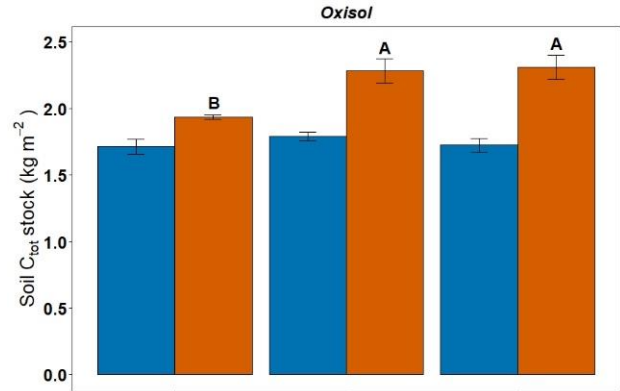

(a)

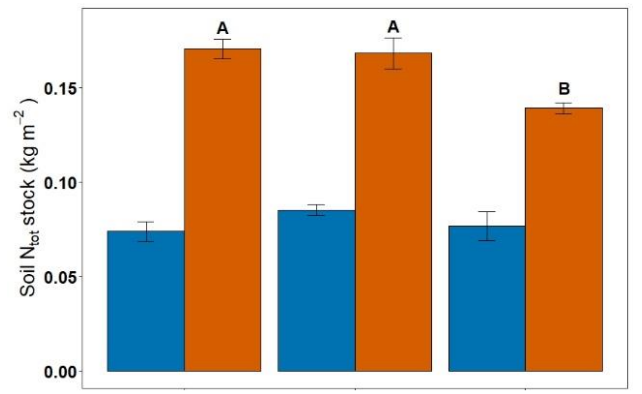

(c)

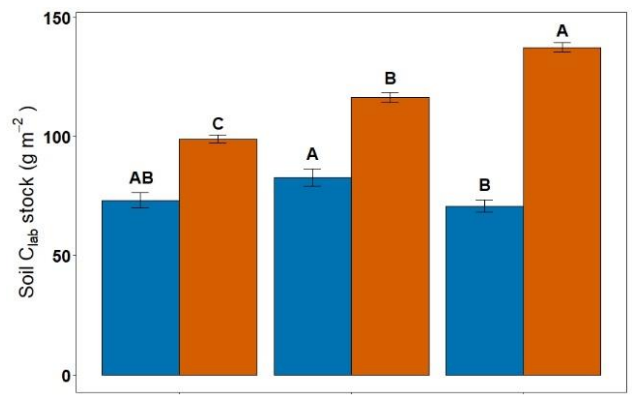

(e)

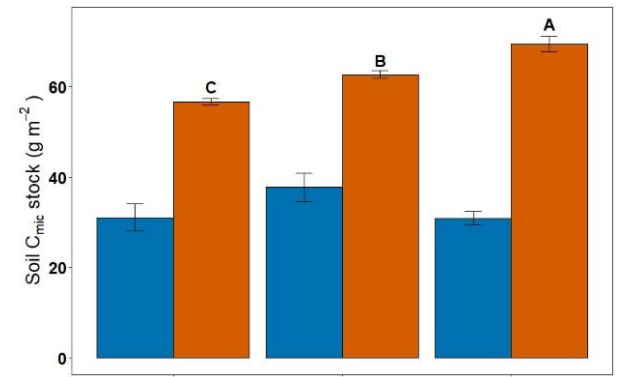

(g)

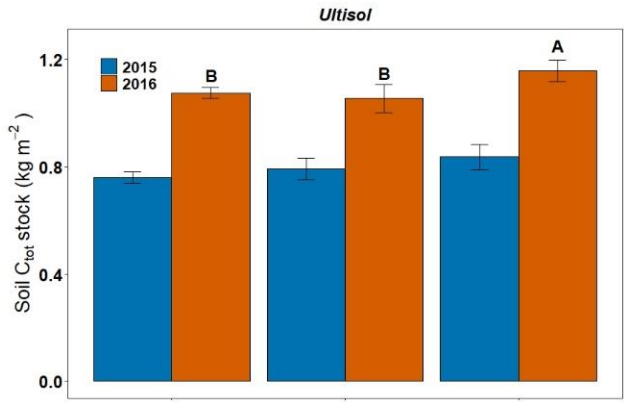

(b)

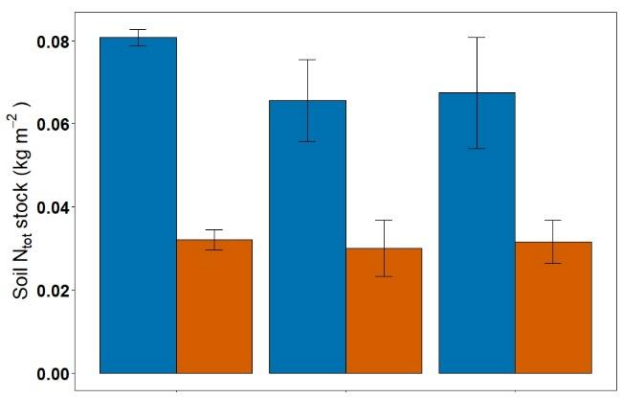

(d)

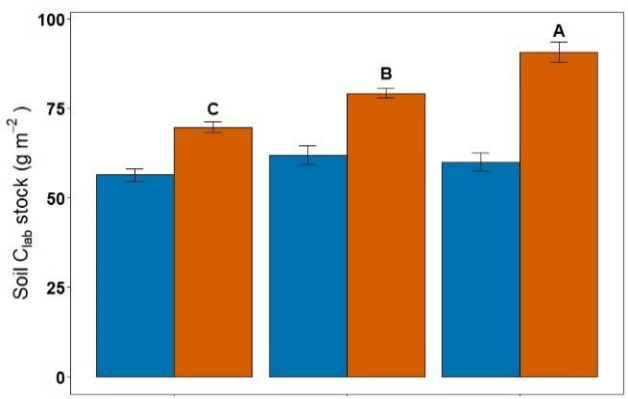

(f)

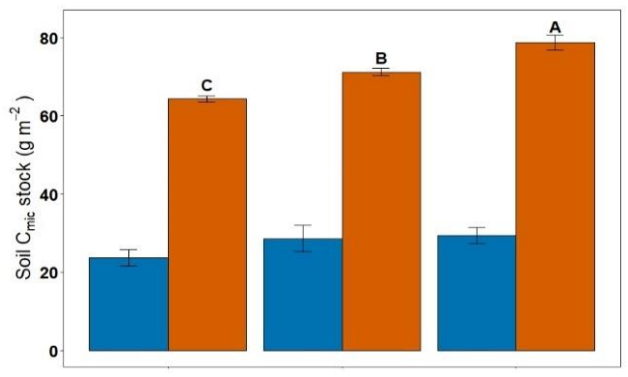

(h)

Figure 3. Cont. 


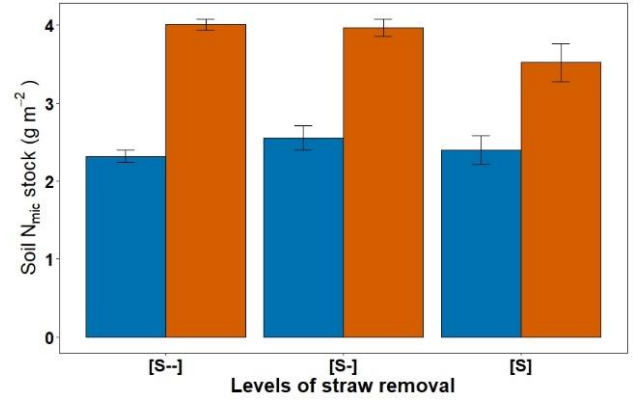

(i)

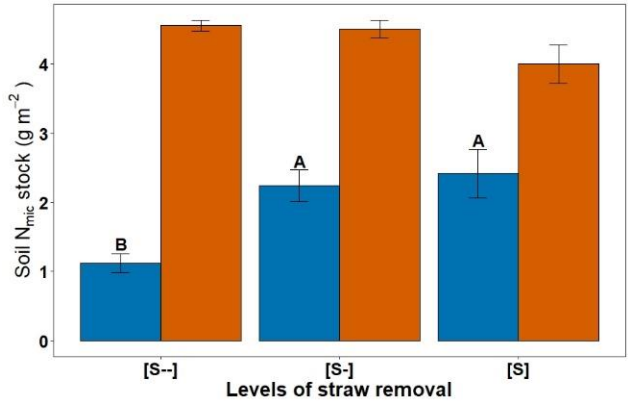

(j)

Figure 3. Soil C and N stocks. Soil C, N, labile C, microbial C, and microbial N stocks in the $0-10 \mathrm{~cm}$ soil layer under levels of sugarcane straw removal in October 2015 and in October 2016. Soil $C_{\text {tot }}$ stock (a); soil $\mathrm{N}_{\text {tot }}$ stock (c); soil $\mathrm{C}_{\text {lab }}$ stock (e); soil $\mathrm{C}_{\text {mic }}$ stock (g); soil $\mathrm{N}_{\text {mic }}$ stock (i) in the Oxisol site and Soil $\mathrm{C}_{\text {tot }}$ stock (b); soil $\mathrm{N}_{\text {tot }}$ stock (d); soil $\mathrm{C}_{\text {lab }}$ stock (f); soil $\mathrm{C}_{\text {mic }}$ stock (h); soil $\mathrm{N}_{\text {mic }}$ stock (j) in the Ultisol site ([S- -]: total removal; [S-]: moderate removal; [S]: no removal). Each bar represents the Mean $(n=4)$ \pm S.D.; same letter in soil sampling time did not differ according to Tukey's test $(p<0.10)$.

\subsection{Soil Carbon and Nitrogen Indexes}

In both sites, the impacts of straw removal management on soil $\mathrm{C}$ and $\mathrm{N}$ indexes were greatest in the second year of analysis and yet the effects of straw removal were more apparent for the Oxisol compared to the Ultisol site (Supplementary material, Table S2). In 2016 in the Oxisol site, difference in soil $\mathrm{C}_{\text {tot }}: \mathrm{N}_{\text {tot }}$ ratio between the straw managements decreased with sugarcane straw removal and the highest soil $\mathrm{C}_{\text {lab }}: \mathrm{C}_{\text {tot }}$ and $\mathrm{C}_{\text {mic }}: \mathrm{N}_{\text {mic }}$ ratios were recorded under [S] $(p<0.10$; Supplementary material, Table S2). Similar pattern was observed for the $C_{m i c}: C_{t o t}$ ratio, which differed significantly among [S- -] and [S] straw managements $(p<0.10$; Supplementary material, Table S2). In the Ultisol site, the $\mathrm{C}_{\text {lab }}: \mathrm{C}_{\text {tot }}$ ratio became lower with increasing straw removal from the field $(p<0.10$; Supplementary material, Table S2). In contrast, soil $\mathrm{C}_{m i c}: \mathrm{C}_{\text {lab }}$ ratio was higher for total removal of straw [S- -], while the highest soil $\mathrm{C}_{\text {mic }}: \mathrm{N}_{\text {mic }}$ ratio was found under [S] $(p<0.10$; Supplementary material, Table S2).

In 2015, straw removal affected only the $\mathrm{N}_{m i c}: \mathrm{N}_{\text {tot }}$ and $\mathrm{C}_{m i c}: \mathrm{N}_{\text {mic }}$ ratios in the Ultisol site. The highest soil $\mathrm{N}_{\text {mic }}: \mathrm{N}_{\text {tot }}$ ratio was recorded under [S-] and [S] straw managements, with no difference between them, while the $\mathrm{C}_{\text {mic }}: \mathrm{N}_{\text {mic }}$ ratio was the highest in the soil with total straw removal $(p<0.10$; Supplementary material, Table S2).

Overall, in the Ultisol site, the straw management improved the soil organic matter quality indexes between the years. Such increments with time was also observed in the Oxisol site for the $\mathrm{C}_{\text {lab }}: \mathrm{C}_{\text {tot }}$ and $\mathrm{C}_{\text {mic }}: \mathrm{C}_{\text {tot }}$ ratios.

\subsection{Soil Physical Fractionation of Soil Organic Matter}

In the Oxisol site, the soil $C_{\text {tot }}$ concentration in the $0-5$ and 5-10 $\mathrm{cm}$ depths for each straw management was the highest in the smallest organic fraction $(<53 \mu \mathrm{m})$ (Figure $4 \mathrm{a}, \mathrm{b})$, which was affected by straw removal. The lowest soil C concentration was reported under the [S- -] straw management in both soil layers and both sites (Figure 4a,c).

In both sites, the particles with sizes smaller than $2.000 \mu \mathrm{m}$ and bigger than $53 \mu \mathrm{m}$ represented from $15 \%$ to $30 \%$ of the $C_{\text {tot }}$ concentration (Figure $4 \mathrm{~b}, \mathrm{~d}$ ), in contrast, sugarcane straw management had no effect on this specific fraction of soil organic matter. Straw removal reduced soil C content of FOM in both soil depths for the two sites. This fraction decreased with depth and constituted about $5 \%$ of the $\mathrm{C}_{\text {tot }}$ in both sites. 


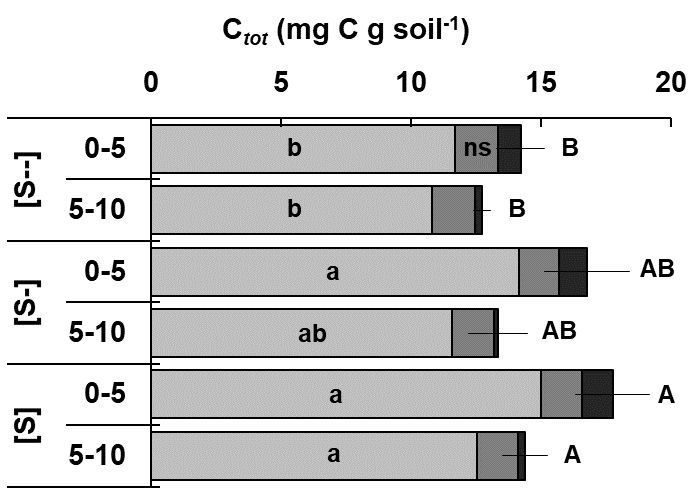

(a)

\begin{tabular}{|c|c|c|c|c|}
\hline & \multicolumn{2}{|c|}{0} & 10 & 20 \\
\hline$T$ & $0-5$ & b & $n s-B$ & \\
\hline$\underline{G}$ & $5-10$ & b & B & \\
\hline$T$ & $0-5$ & $a$ & $-A$ & \\
\hline o & $5-10$ & $a$ & A & $\square<53$ um \\
\hline 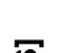 & $0-5$ & $a$ & $A$ & 口 2000 - 53 um \\
\hline & $5-10$ & a & $-A$ & - FOM \\
\hline
\end{tabular}

(c)
Relative distribution $(\% \mathrm{C})$

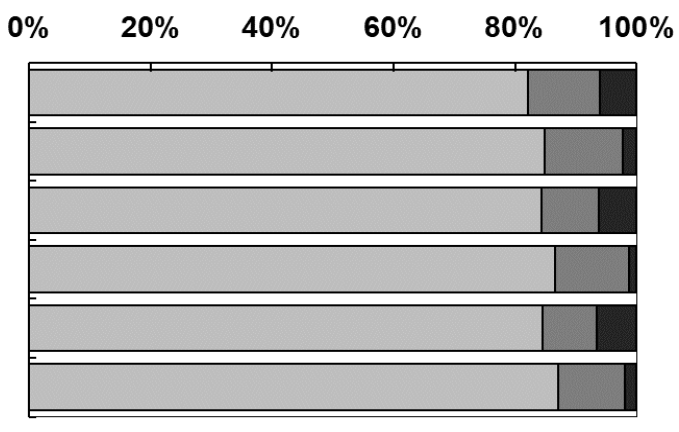

(b)

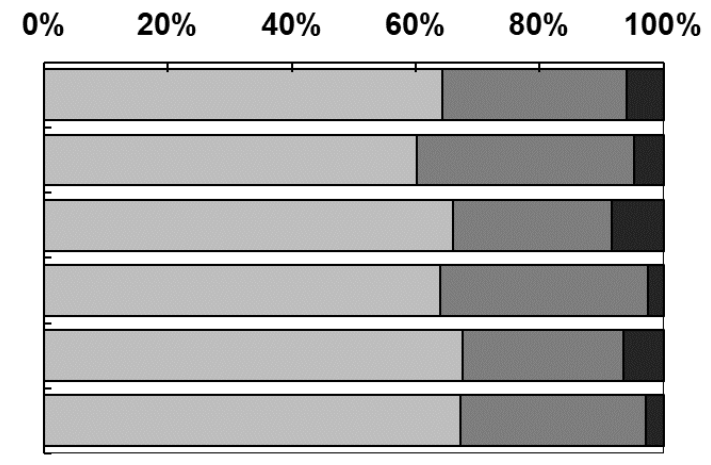

(d)

Figure 4. Soil physical fractionation of SOM in the $0-5$ and 5-10 cm soil layer under levels of sugarcane straw removal in second year sampling, C-content in each fraction (a) in the Oxisol and (c) in the Ultisol; relative distribution of C-content in fractions (b) in the Oxisol site and (d) in the Ultisol site. ([S- -]: total removal; [S-]: moderate removal; [S]: no removal). Bars represents the Mean $(n=4) \pm$ S.D.; same small letter in each fraction and capital letter in each soil layer in each site did not differ according to Tukey's test $(p<0.10)$; ns = not significant.

\section{Discussion}

The effects of crop residue removal for bioenergy production on soil functioning have been widely investigated in recent years $[5,9,24]$. One of the most important tradeoffs associated with crop residue removal is soil $\mathrm{C}$ depletion $[9,42]$. Our findings indicated that total sugarcane straw removal depleted stocks of soil organic $C$ fractions, while the moderate removal did not show any significant difference with no removal of straw.

Crop residues sustain or increase SOM by direct and indirect mechanisms. Straw contains about $50 \%$ of $C$, being the principal $C$ input into the soil (i.e., $70 \%$ ) in sugarcane fields [43,44]. A recent literature review revealed that straw maintenance on soil surface in Brazilian sugarcane fields promoted a soil C accretion at annual rate of $0.81 \pm 0.56 \mathrm{Mg} \mathrm{ha}^{-1} \mathrm{yr}^{-1}$ and $1.37 \pm 0.62 \mathrm{Mg} \mathrm{ha}^{-1} \mathrm{yr}^{-1}$ for $0-0.3 \mathrm{~m}$ and 0-1.0 m layers, respectively [9]. Concerns about the relevance of crop residues on soil $C$ was also reported through a meta-analysis study on corn stover management in areas mainly located in the USA and China [45]. The authors showed that corn stover retention promoted soil $\mathrm{C}$ accretion by $0.41 \mathrm{Mg} \mathrm{ha}^{-1} \mathrm{yr}^{-1}$, and that a moderate residue removal $(<50 \%)$ may induce a greater soil C accumulation, even compared to managements with stover removal.

In our study, the changes in soil $\mathrm{C}$ and $\mathrm{N}$ fractions caused by straw management were detected only in 2016, after two successive years of straw management. These results corroborate those found by Bordonal et al. [8] who showed that after two years of complete straw removal, the soil C stocks depleted significantly while intermediate intensity and no straw removal did not affect soil C stocks. 
The lowest soil C stock observed under total removal of straw (Figure $3 a, b)$ may be associated to the absence of $C$ input and this result indicates the influence of straw removal on soil $C$ accumulation rates, as observed previously in a sugarcane field in Australia [46]. The soil's chemical and physical properties can also influence SOM stabilization [47], for instance, clayey soils may sustain greater $\mathrm{C}$ stocks related to sandy soils. That fact is supported by the evidence that soil physicochemical characteristics determine the maximum soil C storage potential [4]. Soil type and clay content were also demonstrated to influence the rate of SOC changes [48].

Another benefit provided by straw is the soil cover [49] and physical protection against water and wind erosion [50], which reduces soil and SOM losses [13]. The straw supplies $C$ to soil, which enhances the soil aggregate stability and ameliorates soil structure quality [51,52]. The aggregate formation and stabilization provided by straw provides physical protection of SOM from microbial oxidation which induces SOM accumulation [51]. The residue removal from the soil surface reduces the aggregation stability and, consequently, SOM decreases over time and the $\mathrm{C}$ contents are depleted [9]. This fact might explain the lower contents of soil $C$ fractions under straw removal compared to no removal found in both sites in our study (Figure 3). Complete straw removal on a short-term basis decreases the labile fractions of soil organic matter, and thereby in a long-term perspective this can impair critical soil processes related to soil organic matter. Although two years is not enough to assess soil total carbon sequestration, changes in soil carbon and nitrogen fractions can indicate changes in soil carbon within this short period [53].

The study of SOM forms contributes to investigate its dynamics and predict its response to soil use and management [28]. A strong relation between the size of fraction and the physical quality of soil organic matter has been reported in the literature [40]. It has been shown that fine stable aggregates $(<53 \mu \mathrm{m})$, when destabilized, are useful to soil microorganisms and plants as source of labile-C [28]. A recent evidence suggests that sugarcane management leaves $14 \mathrm{Mg} \mathrm{ha}^{-1} \mathrm{yr}^{-1}$ of straw on the soil surface which promotes an increase of $60 \%$ of total soil C, and the smallest fraction of organic matter $(<53 \mu \mathrm{m})$ had the greatest increment [52]. The current study found that straw removal led to a decrease in the $<0.53 \mu \mathrm{m}$ fraction compared to moderate or no removal of straw (Figure 4). It is also supported by Brandani et al. [54] who observed a similar trend after 4 and 12 years with inputs of sugarcane residues, whose highest $C$ concentration was also found mainly in the $<0.53 \mu \mathrm{m}$ fraction in the $0-5 \mathrm{~cm}$ soil layer. The results of SOM physical fractionation found in the current study reinforced these findings, with increases in $\mathrm{C}_{\text {tot }}$ under [S-] and [S] through inputs of organic $\mathrm{C}$ mainly to the fine soil particles (Figure 4).

Studies investigating the decomposition of sugarcane straw suggest that the straw $\mathrm{C}$ decomposition is influenced by the amount of straw left on the soil surface. Carbon released into the soil is higher under no straw removal in comparison with straw removal in different rates [55]. It has been observed that $C$ released by sugarcane straw decomposition over a period of 180 days is between 0.5 and 3.1 $\mathrm{Mg} \mathrm{ha}^{-1}$ [56]. Some studies used a modeling approach to explore the effects of long-term straw management on soil C stocks [17,57]. A simulation using DayCent model predicted that no removal of sugarcane residue contributed to an increase in soil C stocks of 2.8 to $5.7 \mathrm{Mg} \mathrm{ha}^{-1}$ in a period of 30 years [17]. In agreement with that, a simulated model to predict soil $C$ stock changes in sugarcane verified losses rate of $0.19 \mathrm{Mg} \mathrm{ha}^{-1} \mathrm{yr}^{-1}$ under $75 \%$ of straw removal and accretion rate of $0.11 \mathrm{Mg} \mathrm{ha}^{-1} \mathrm{yr}^{-1}$ when straw was not removed from fields [57].

We also found a decrease in the contents of labile and microbial $C$ when straw was removed (Figure 3e-h). This result may be explained by the fact that the input of $C$ to soil stimulates the biological activity and increases microbial biomass, which promotes greater decomposition process [58]. On the other hand, the straw removal results in soil microbial biomass decline [58]. It was in accordance with data shown by [50], which a portion of $C$ derived from straw enters into the soil as labile organic $C$ pool. Additionally, a greater protection and increase in $\mathrm{C}$ in humic substance fractions in areas where there is a minimum tillage of soil was reported by Lopes [59]. Studies using stable isotopes of $C\left(\delta^{13} C\right)$ 
have shown that a greater proportion (about $60 \%$ ) of soil C is derived from the straw in the sugarcane field, which indicates that the humification process was stimulated [54].

The results of this study suggest that $8-10 \mathrm{Mg} \mathrm{ha}^{-1}$ of straw can be enough to sustain soil organic matter quality indexes and the excesses of straw can be used for bioenergy use. Therefore, straw removal should be considered as a feasible management only in sites with high straw-producing potential, while straw should be preserved in sites with low straw production [57]. This finding showed the importance of assessing the impacts of straw removal to verify the effectiveness of residue management and the better understanding of how much straw can be removed from the sugarcane fields.

Although this study focused on the effects of sugarcane straw removal on soil $\mathrm{C}$ fractions, there are several soil and plant parameters that must be taken into account to establish the amount of straw that can be removed without impairment of the soil quality and plant growth $[5,9,11]$. It is essential to guide the sugarcane sector to remove straw in a sustainable way, preserving soil and crop yields and increasing bioenergy production in the coming years.

\section{Conclusions}

This study provides information to guide decision-making on the optimum amount of straw to be maintained in sugarcane fields to sustain soil health while providing feedstock for bioenergy production in Brazil. Excessive straw removal depletes soil organic matter pools, especially labile and microbial-C stocks. The adoption of moderate straw removal can be a suitable management strategy to control the depletion of labile soil organic matter fractions since 8-10 $\mathrm{Mg} \mathrm{ha}^{-1}$ of straw left in the field did not have a negative impact on SOM fractions.

We also emphasize that long-term monitoring of soil health changes is fundamental to design sustainable straw management, not only considering soil $\mathrm{C}$ changes but also including soil chemical and physical aspects, and crop responses. Additionally, it should be emphasized that a fully effective straw removal management must be coupled with the adoption of best management practices, such as the use of no-tillage, crop rotation and organic amendments [9,57], which helps to mitigate the negative effects of straw removal [54].

Supplementary Materials: The following are available online at http://www.mdpi.com/2071-1050/12/22/9363/s1, Table S1: Contents of total organic carbon $\left(\mathrm{C}_{\text {tot }}\right)$, total nitrogen $\left(\mathrm{N}_{t o t}\right)$, labile carbon $\left(\mathrm{C}_{\text {lab }}\right)$, microbial biomass carbon $\left(\mathrm{C}_{\text {mic }}\right)$, and microbial biomass nitrogen $\left(\mathrm{N}_{\text {mic }}\right)$ in the $0-10 \mathrm{~cm}$ soil layer under levels of sugarcane straw removal., Table S2: Soil organic matter quality indexes $\left(\mathrm{C}_{\text {tot }}: \mathrm{N}_{t o t}, \mathrm{C}_{\text {lab }}: \mathrm{C}_{t o t}, \mathrm{C}_{\text {mic }}: \mathrm{C}_{l a b}, \mathrm{C}_{\text {mic }}: \mathrm{C}_{t o t}, \mathrm{~N}_{\text {mic }}: \mathrm{N}_{t o t}\right.$ and $\left.\mathrm{C}_{\text {mic }}: \mathrm{N}_{\text {mic }}\right)$ in the 0-10 $\mathrm{cm}$ soil surface under different sugarcane straw level.

Author Contributions: Conceptualization, C.E.P.C.; Data curation, M.C.M. and M.R.C.; Formal analysis, M.S.-N., H.P.G. and L.S.S.; Funding acquisition, M.C.M., M.S.-N. and M.R.C.; Methodology, M.C.M.; Project administration, C.E.P.C. and M.R.C.; Supervision, B.J.F.; Validation, M.S.-N.; Writing—original draft, M.C.M.; Writing—review and editing, M.S.-N., A.S. and M.R.C. All authors have read and agreed to the published version of the manuscript.

Funding: This research was funded by Coordenação de Aperfeiçoamento de Pessoal de Nível Superior-Brasil (CAPES)—Finance Code 001, and São Paulo Research Foundation (FAPESP), grant number \#2018/09845-7. MSN was founded by the Conselho Nacional de Desenvolvimento Científico e Tecnológico (CNPq), grant number Brazil \#380421/2015.-

Acknowledgments: We would like to acknowledge Carlos Clemente Cerri (in memoriam) for guiding us during the research and the technicians Lilian Duarte, Admilson Margato and Ralf Araújo for their assistance in the experiment conduction. Thanks to Luiz Antonio Martinelli for suggesting critical points in writing.

Conflicts of Interest: The authors declare no conflict of interest.

\section{References}

1. Hussain, A.; Arif, S.M.; Aslam, M. Emerging renewable and sustainable energy technologies: State of the art. Renew. Sustain. Energy Rev. 2017, 71, 12-28. [CrossRef]

2. Global Energy \& CO2 Status Report 2019. Available online: https://www.iea.org/reports/global-energy-co2status-report-2019 (accessed on 7 August 2020).

3. Heck, V.; Gerten, D.; Lucht, W.; Popp, A. Biomass-based negative emissions difficult to reconcile with planetary boundaries. Nat. Clim. Chang. 2018, 8, 151-155. [CrossRef] 
4. Companhia Nacional de Abastecimento. Acompanhamento da Safra Brasileira de Cana-de-Açúcar. Available online: http://www.conab.gov.br (accessed on 30 July 2020).

5. Carvalho, J.L.N.; Nogueirol, R.C.; Menandro, L.M.S.; Bordonal, R.D.O.; Borges, C.D.; Cantarella, H.; Franco, H.C.J. Agronomic and environmental implications of sugarcane straw removal: A major review. GCB Bioenergy 2017, 9, 1181-1195. [CrossRef]

6. Barbosa, C.M.G.; Terra-Filho, M.; De Albuquerque, A.L.P.; Di Giorgi, D.; Grupi, C.; Negrão, C.E.; Rondon, M.U.P.B.; Martinez, D.G.; Marcourakis, T.; Dos Santos, F.A.; et al. Burnt Sugarcane HarvestingCardiovascular Effects on a Group of Healthy Workers, Brazil. PLoS ONE 2012, 7, e46142. [CrossRef]

7. Aguiar, D.A.; Rudorff, B.F.T.; Silva, W.F.; Adami, M.; Mello, M.P. Remote Sensing Images in Support of Environmental Protocol: Monitoring the Sugarcane Harvest in São Paulo State, Brazil. Remote Sens. 2011, 3, 2682-2703. [CrossRef]

8. Bordonal, R.D.O.; Carvalho, J.L.N.; Lal, R.; De Figueiredo, E.B.; De Oliveira, B.G.; La Scala, N. Sustainability of sugarcane production in Brazil. A review. Agron. Sustain. Dev. 2018, 38, 13. [CrossRef]

9. Cherubin, M.R.; Oliveira, D.M.S.; Feigl, B.J.; Pimentel, L.G.; Lisboa, I.P.; Gmach, M.R.; Varanda, L.L.; Morais, M.C.; Satiro, L.S.; Popin, G.V.; et al. Crop residue harvest for bioenergy production and its implications on soil functioning and plant growth: A review. Sci. Agric. 2018, 75, 255-272. [CrossRef]

10. Menandro, L.M.S.; Cantarella, H.; Franco, H.C.J.; Kölln, O.T.; Pimenta, M.T.B.; Sanches, G.M.; Rabelo, S.C.; Carvalho, J.L.N. Comprehensive assessment of sugarcane straw: Implications for biomass and bioenergy production. Biofuels Bioprod. Biorefin. 2017, 11, 488-504. [CrossRef]

11. Galdos, M.V.; Cantarella, H.; Hastings, A.; Hillier, J.; Smith, P. Environmental sustainability aspects of second generation ethanol production from sugarcane. In Advances of Basic Science for Second Generation Bioethanol from Sugarcane; Buckeridge, M., De Souza, A., Eds.; Springer International Publishing: Cham, Switzerland, 2017; pp. 177-195.

12. Fortes, C.; Trivelin, P.C.O; Vitti, A.C. Long-term decomposition of sugarcane harvest residues in Sao Paulo state, Brazil. Biomass Bioenergy 2012, 42, 189-198. [CrossRef]

13. De Sousa, G.B.; Filho, M.V.M.; Matias, S.S.R. Soil, organic matter and nutrients losses by water erosion in a slope with sugarcane straw, in Guariba, State of São Paulo. Eng. Agric. 2012, 32, 490-500. [CrossRef]

14. Souza, R.A.; Telles, T.S.; Machado, W.; Hungria, M.; Filho, J.T.; Guimarães, M.D.F. Effects of sugarcane harvesting with burning on the chemical and microbiological properties of the soil. Agric. Ecosyst. Environ. 2012, 155, 1-6. [CrossRef]

15. dos Anjos, J.C.R.; de Andrade Júnior, A.S.; Bastos, E.A.; Noleto, D.H.; de Brito Melo, F.; De Brito, R.R. Water storage in a Plinthaqualf cultivated with sugarcane under straw levels. Pesqui. Agropecu. Bras. 2017, 52, 464-473. [CrossRef]

16. Corrêa, S.T.R.; Barbosa, L.C.; Menandro, L.M.S.; Scarpare, F.V.; Reichardt, K.; De Moraes, L.O.; Hernandes, T.A.D.; Franco, H.C.J.; Carvalho, J.L.N. Straw Removal Effects on Soil Water Dynamics, Soil Temperature, and Sugarcane Yield in South-Central Brazil. BioEnergy Res. 2019, 12, 749-763. [CrossRef]

17. Carvalho, J.L.N.; Hudiburg, T.W.; Franco, H.C.J.; DeLucia, E.H. Contribution of above- and belowground bioenergy crop residues to soil carbon. GCB Bioenergy 2017, 9, 1333-1343. [CrossRef]

18. Lal, R. Soil Carbon Sequestration Impacts on Global Climate Change and Food Security. Science 2004, 304, 1623-1627. [CrossRef] [PubMed]

19. Lal, R. Managing Soils and Ecosystems for Mitigating Anthropogenic Carbon Emissions and Advancing Global Food Security. Bioscience 2010, 60, 708-721. [CrossRef]

20. Food and Agriculture Organization of the United Nations. Soil Organic Carbon: The Hidden Potential; FAO: Rome, Italy, 2017.

21. Hoffland, E.; Kuyper, T.W.; Comans, R.N.; Creamer, R. Eco-functionality of organic matter in soils. Plant Soil 2020, 455, 1-22. [CrossRef]

22. Wiesmeier, M.; Urbanski, L.; Hobley, E.U.; Lang, B.; Von Lützow, M.; Marin-Spiotta, E.; Van Wesemael, B.; Rabot, E.; Ließ, M.; Garcia-Franco, N.; et al. Soil organic carbon storage as a key function of soils-A review of drivers and indicators at various scales. Geoderma 2019, 333, 149-162. [CrossRef]

23. Lal, R. Soil health and carbon management. Food Energy Secur. 2016, 5, 212-222. [CrossRef]

24. Blanco-Canqui, H.; Lal, R. Crop Residue Removal Impacts on Soil Productivity and Environmental Quality. Crit. Rev. Plant Sci. 2009, 28, 139-163. [CrossRef] 
25. Rowe, R.L.; Keith, A.M.; Elias, D.M.O.; McNamara, N.P. Soil carbon stock impacts following reversion of Miscanthus $\times$ giganteus and short rotation coppice willow commercial plantations into arable cropping. GCB Bioenergy 2020, 12, 680-693. [CrossRef]

26. Balota, E.L.; Colozzi-Filho, A.; Andrade, D.S.; Dick, R.P. Microbial biomass in soils under different tillage and crop rotation systems. Biol. Fertil. Soils 2003, 38, 15-20. [CrossRef]

27. Lupwayi, N.; Rice, W.; Clayton, G. Soil microbial diversity and community structure under wheat as influenced by tillage and crop rotation. Can. J. Soil Sci. 1999, 79, 273-280. [CrossRef]

28. Fischer, H.; Ingwersen, J.; Kuzyakov, Y. Microbial uptake of low-molecular-weight organic substances out-competes sorption in soil. Eur. J. Soil Sci. 2010, 61, 504-513. [CrossRef]

29. Lavallee, J.M.; Soong, J.L.; Cotrufo, M.F. Conceptualizing soil organic matter into particulate and mineral-associated forms to address global change in the 21st century. Glob. Chang. Biol. 2019, 26, 261-273. [CrossRef] [PubMed]

30. Sparling, G. Ratio of microbial biomass carbon to soil organic carbon as a sensitive indicator of changes in soil organic matter. Soil Res. 1992, 30, 195-207. [CrossRef]

31. Shrestha, R.K.; Ladha, J.K.; Lefroy, R.D. Carbon management for sustainability of an intensively managed rice-based cropping system. Biol. Fertil. Soils 2002, 36, 215-223. [CrossRef]

32. Chen, Z.; Wang, H.; Liu, X.; Zhao, X.; Lu, D.; Zhou, J.; Li, C. Changes in soil microbial community and organic carbon fractions under short-term straw return in a rice-wheat cropping system. Soil Tillage Res. 2017, 165, 121-127. [CrossRef]

33. Soil Survey Staff. Keys to Soil Taxonomy, 12th ed.; USDA-Natural Resources Conservation Service: Washington, DC, USA, 2014.

34. Lisboa, I.P.; Cherubin, M.R.; Cerri, C.E.P.; Cerri, D.G.; Cerri, C.E.P. Guidelines for the recovery of sugarcane straw from the field during harvesting. Biomass Bioenergy 2017, 96, 69-74. [CrossRef]

35. Vance, E.; Brookes, P.; Jenkinson, D. An extraction method for measuring soil microbial biomass C. Soil Biol. Biochem. 1987, 19, 703-707. [CrossRef]

36. Sparling, G.; West, A. A direct extraction method to estimate soil microbial C: Calibration in situ using microbial respiration and 14C labelled cells. Soil Biol. Biochem. 1988, 20, 337-343. [CrossRef]

37. Brookes, P.; Landman, A.; Pruden, G.; Jenkinson, D. Chloroform fumigation and the release of soil nitrogen: A rapid direct extraction method to measure microbial biomass nitrogen in soil. Soil Biol. Biochem. 1985, 17, 837-842. [CrossRef]

38. Beck, T.; Joergensen, R.; Kandeler, E.; Makeschin, F.; Nuss, E.; Oberholzer, H.; Scheu, S. An inter-laboratory comparison of ten different ways of measuring soil microbial biomass C. Soil Biol. Biochem. 1997, 29, 1023-1032. [CrossRef]

39. Lee, J.; Hopmans, J.W.; Rolston, D.E.; Baer, S.G.; Six, J. Determining soil carbon stock changes: Simple bulk density corrections fail. Agric. Ecosyst. Environ. 2009, 134, 251-256. [CrossRef]

40. Signor, D.; Zani, C.F.; Paladini, A.A.; Deon, M.D.; Cerri, C.E.P. Estoques de carbono e qualidade da matéria orgânica do solo em áreas cultivadas com cana-de-açúcar. Rev. Bras. Cienc. Solo 2014, 38, 1402-1410. [CrossRef]

41. Christensen, B.T. Physical Fractionation of Soil and Organic Matter in Primary Particle Size and Density Separates. Adv. Soil Sci. 1992, 20, 1-77. [CrossRef]

42. Smith, W.; Grant, B.; Campbell, C.; McConkey, B.G.; Desjardins, R.L.; Kröbel, R.; Malhi, S. Crop residue removal effects on soil carbon: Measured and inter-model comparisons. Agric. Ecosyst. Environ. 2012, 161, 27-38. [CrossRef]

43. Carvalho, J.L.N.; Otto, R.; Franco, H.C.J.; Trivelin, P.C. Input of sugarcane post-harvest residues into the soil. Sci. Agric. 2013, 70, 336-344. [CrossRef]

44. Thorburn, P.; Meier, E.; Collins, K.; Robertson, F. Changes in soil carbon sequestration, fractionation and soil fertility in response to sugarcane residue retention are site-specific. Soil Tillage Res. 2012, 120, 99-111. [CrossRef]

45. Xu, H.; Sieverding, H.; Kwon, H.; Clay, D.; Stewart, C.; Johnson, J.M.F.; Qin, Z.; Karlen, D.L.; Wang, M. A global meta-analysis of soil organic carbon response to corn stover removal. GCB Bioenergy 2019, 11, 1215-1233. [CrossRef]

46. Robertson, F.A.; Thorburn, P. Decomposition of sugarcane harvest residue in different climatic zones. Aust. J. Soil Res. 2007, 45, 1-11. [CrossRef]

47. Six, J.; Conant, R.T.; Paul, E.A.; Paustian, K. Stabilization mechanisms of soil organic matter: Implications for C-saturation of soils. Plant Soil 2002, 241, 155-176. [CrossRef] 
48. Blanco-Canqui, H.; Lal, R. Soil structure and organic carbon relationships following 10 years of wheat straw management in no-till. Soil Tillage Res. 2007, 95, 240-254. [CrossRef]

49. Silva, A.G.B.; Lisboa, I.P.; Cherubin, M.R.; Cerri, C.E.P. How Much Sugarcane Straw is Needed for Covering the Soil? BioEnergy Res. 2019, 12, 858-864. [CrossRef]

50. Silva, A.P.; Babujia, L.C.; Dos Santos, J.C.F.; Ralisch, R.; Hungria, M.; Guimarães, M.D.F. Soil structure and its influence on microbial biomass in different soil and crop management systems. Soil Tillage Res. 2014, 142, 42-53. [CrossRef]

51. Tormena, C.A.; Karlen, D.L.; Logsdon, S.; Cherubin, M.R. Visual Soil Structure Effects of Tillage and Corn Stover Harvest in Iowa. Soil Sci. Soc. Am. J. 2016, 80, 720-726. [CrossRef]

52. Castioni, G.A.; Cherubin, M.R.; Menandro, L.M.S.; Sanches, G.M.; Bordonal, R.D.O.; Barbosa, L.C.; Franco, H.C.J.; Carvalho, J.L.N. Soil physical quality response to sugarcane straw removal in Brazil: A multi-approach assessment. Soil Tillage Res. 2018, 184, 301-309. [CrossRef]

53. Akinsete, S.J.; Nkongolo, N. Soil Carbon and Nitrogen Fractions of a Grassland in Central Missouri, USA. Commun. Soil Sci. Plant Anal. 2016, 47, 1128-1136. [CrossRef]

54. Brandani, C.B.; Abbruzzini, T.F.; Conant, R.T.; Cerri, C.E.P. Soil organic and organomineral fractions as indicators of the effects of land management in conventional and organic sugar cane systems. Soil Res. 2016, 55, 145. [CrossRef]

55. Pimentel, L.G.; Cherubin, M.R.; Oliveira, D.M.; Cerri, C.E.; Cerri, C.C. Decomposition of sugarcane straw: Basis for management decisions for bioenergy production. Biomass Bioenergy 2019, 122, 133-144. [CrossRef]

56. Vasconcelos, A.L.S.; Cherubin, M.R.; Feigl, B.J.; Cerri, C.E.; Gmach, M.R.; Siqueira-Neto, M. Greenhouse gas emission responses to sugarcane straw removal. Biomass Bioenergy 2018, 113, 15-21. [CrossRef]

57. Oliveira, D.M.D.S.; Williams, S.; Cerri, C.E.P.; Paustian, K. Predicting soil C changes over sugarcane expansion in Brazil using the DayCent model. GCB Bioenergy 2017, 9, 1436-1446. [CrossRef]

58. Di Lonardo, D.P.; De Boer, W.; Zweers, H.; Van Der Wal, A. Effect of the amount of organic trigger compounds, nitrogen and soil microbial biomass on the magnitude of priming of soil organic matter. PLoS ONE 2019, 14, e0216730. [CrossRef] [PubMed]

59. Lopes, I.M.; Assunção, S.A.; De Oliveira, A.P.P.; Dos Anjos, L.H.C.; Pereira, M.G.; Lima, E. Carbon fractions and soil fertility affected by tillage and sugarcane residue management an Xanthic Udult. Semin. Ciênc. Agrar. 2017, 38, 2921. [CrossRef]

Publisher's Note: MDPI stays neutral with regard to jurisdictional claims in published maps and institutional affiliations.

(C) 2020 by the authors. Licensee MDPI, Basel, Switzerland. This article is an open access article distributed under the terms and conditions of the Creative Commons Attribution (CC BY) license (http://creativecommons.org/licenses/by/4.0/). 